\title{
HARGA DIRI, EFIKASI DIRI, MOTIVASI BELAJAR, DAN PRESTASI AKADEMIK SISWA SMA PADA BERBAGAI MODEL PEMBELAJARAN
}

\author{
Dinda Ayu Novariandhini ${ }^{1}$, Melly Latifah ${ }^{1^{*}}$ \\ ${ }^{1}$ Departemen IImu Keluarga dan Konsumen, Fakultas Ekologi Manusia, Institut Pertanian Bogor, \\ Bogor 16680, Indonesia \\ *) E-mail: mellylatifah@yahoo.com
}

\begin{abstract}
Abstrak
Penelitian ini bertujuan untuk menganalisis harga diri, efikasi diri, motivasi belajar, dan prestasi akademik siswa SMA pada berbagai model pembelajaran yang melibatkan 26 siswa kelas akselerasi, 30 siswa kelas internasional, dan 30 Siswa kelas reguler di Kota Bogor. Ketiga kelas tersebut mewakili masing-masing model pembelajaran dalam penelitian ini. Pengambilan data dilakukan dengan teknik pelaporan diri dengan alat bantu kuesioner. Penelitian ini menggunakan analisis deskriptif dan statistik inferensia. Hasil penelitian menemukan adanya perbedaan motivasi intrinsik siswa berdasarkan tiga model pembelajaran. Hasil penelitian juga menunjukkan adanya perbedaan nilai evaluasi siswa di ketiga kelas yaitu kelas akselerasi memiliki nilai kognitif dan psikomotorik yang paling tinggi. Penelitian ini juga menemukan hubungan yang signifikan positif antara harga diri dengan efikasi diri, motivasi intrinsik, dan motivasi ekstrinsik. Selain itu, hasil penelitian menemukan hubungan yang signifikan positif antara efikasi diri dengan motivasi intrinsik dan ekstrinsik. Hasil penelitian juga menunjukkan adanya hubungan yang negatif antara motivasi intrinsik dengan tingkat prestasi kognitif dan psikomotorik siswa.
\end{abstract}

Kata kunci: efikasi diri, harga diri, motivasi belajar, prestasi akademik

\section{Self-esteem, Self-efficacy, Learning Motivation, and Academic Achievement in High School Students on Various Learning Models}

\begin{abstract}
This study aims was to analyze the self-esteem, self-efficacy, learning motivation, and academic achievement of high school students in various learning models that involved 26 students of the acceleration class, 30 students of the international class, and 30 students of the regular class in Bogor City. The third class represent each learning models in this research. Data was collected by self-report with the help of a questionnaire. The study using descriptive and inference analysis. The results found a different intrinsic motivation between students of the three learning models. The results also showed different evaluation results between students of the three classes that was accelerated class had the highest achievement of cognitive and psychomotor. The study also found a positive significant correlation between self-esteem with self-efficacy, intrinsic motivation, and extrinsic motivation. In addition, results found a positive significant correlation between self-efficacy with intrinsic motivation and extrinsic motivation. The results also showed a negative relationship between intrinsic motivation with cognitive and psychomotor achievement level of the students.
\end{abstract}

Keywords: academic achievement, motivation to learn, self-efficacy, self-esteem

\section{PENDAHULUAN}

Sumber daya manusia yang berkualitas merupakan salah satu modal penting untuk pembangunan suatu bangsa. Bangsa yang memiliki sumber daya manusia yang bermutu tinggi akan lebih maju dan mampu bersaing dengan bangsa-bangsa lain. Indikator yang dikenal untuk mengukur kualitas sumber daya manusia suatu negara adalah Human Development Index (HDI). Menurut Human Development Report (2008), HDI Indonesia menempati urutan yang rendah yaitu urutan ke
119 dari 179 negara. Hal ini menunjukkan bahwa Indonesia harus mampu mengejar ketertinggalannya dibandingkan negara lain di dunia. Sehubungan dengan hal tersebut, Indonesia perlu meningkatkan kualitas sumber daya manusia agar mampu menggerakkan roda pembangunan bangsa sehingga bangsa Indonesia mampu bersaing di tingkat global.

Salah satu aspek penting dalam pembangunan sumber daya manusia yang berkualitas adalah aspek pendidikan. Sejak tahun 2001 otonomi daerah telah diberlakukan 
dan menjadikan sektor pendidikan mengalami perubahan dalam aspek pendanaan dan aspek penyelenggaraan pendidikan. Hal tersebut menyebabkan adanya desentralisasi pendidikan meliputi pemberian kewenangan yang lebih luas di bidang kebijakan pendidikan dan aspek pendanaannya dari pemerintah pusat ke pemerintah lokal begitu pula dengan masalah pendanaan (Alisjahbana, 2000). Pemerintah daerah juga berhak untuk menentukan model pembelajaran untuk sekolah yang ada di daerahnya seperti dengan membuka kelas akselerasi, kelas sekolah bertaraf internasional (SBI), dan kelas reguler.

Kelas akselerasi merupakan kelas yang dikhususkan untuk anak-anak yang memiliki nilai dan intelligence quetionent (IQ) di atas rata-rata dan masa pendidikannya hanya ditempuh selama dua tahun, sedangkan kelas $\mathrm{SBI}$ adalah kelas yang mengunakan standar internasional dengan menggunakan dua bahasa pengantar yaitu Bahasa Inggris dan Bahasa Indonesia. Fasilitas di kedua kelas tersebut juga sangat memadai seperti adanya pendingin ruangan, ruang kelas yang cukup luas, dan fasilitas lainnya. Berbeda sekali dengan keadaan kelas reguler yang biasabiasa saja sarana dan prasarananya. Perbedaan yang sangat menonjol dalam hal fasilitas antarketiga kelas tersebut diduga akan mempengaruhi pencapaian prestasi siswa, baik prestasi akademik maupun prestasi nonakademik. Prestasi yang baik dapat dilihat dari bagaimana seseorang dapat meyakinkan dirinya sendiri bahwa ia mampu dan bisa mendapatkan hasil yang baik serta memuaskan. Pengenalan akan diri sendiri dapat meningkatkan prestasi seseorang. Pengenalan terhadap diri sendiri dan keyakinan kuat yang dimiliki oleh seseorang dapat terbentuk dari lingkungan terkecilnya yaitu keluarga. Keluarga merupakan suatu unit terkecil dalam suatu ekosistem. Selain dari keluarga hal tersebut juga bisa terbentuk karena pengaruh lingkungan lebih besarnya lagi yaitu teman sebaya dan sekolah tempat mereka mencari ilmu.

Penilaian seseorang secara umum terhadap dirinya sendiri, baik berupa penilaian negatif maupun penilaian positif yang akhirnya menghasilkan perasaan keberhargaan atau kebergunaan diri dalam menjalani kehidupan disebut dengan harga diri (self-esteem). Individu dengan harga tinggi tidak mudah terpengaruh pada penilaian orang lain mengenai sifat dan kepribadiannya, baik itu positif maupun negatif. Penilaian terhadap diri sendiri dapat membantu seseorang untuk dapat lebih mengenal dirinya sendiri dan potensi apa yang menonjol dari diri sendiri sehingga seseorang dapat mengetahui sejak dini potensi yang dimilikinya dan dapat mengasah potensi tersebut untuk membentuk manusia yang memiliki kualitas sumber daya yang tinggi.

Selain penilaian terhadap diri sendiri hal lain yang penting dalam peningkatan kualitas sumber daya manusia untuk pencapaian prestasi yang tinggi adalah keyakinan seseorang bahwa ia dapat menguasai situasi dan menghasilkan hasil (outcomes) yang positif (Santrock, 2002). Keyakinan seseorang dalam penguasaan situasi ini disebut dengan efikasi diri (self-efficacy). Efikasi diri merupakan keyakinan dan kepercayaan seorang individu akan kemampuannya dalam mengontrol hasil dari usaha yang telah dilakukan. Dengan adanya kepercayaan tersebut, prestasi dan potensi yang dimiliki dapat dikontrol dengan baik sehingga pengoptimalan potensi tersebut dapat meningkatan kualitas sumber daya manusia yang ada di Indonesia. Hal ini dapat menyebabkan kekuatan pemikirannya dan kebergunaan pemikirannya sehingga dapat menyebabkan pencapaian segala sesuatu yang diinginkannya dapat terorganisir dengan baik menggunakan kekuatan penilaian terhadap dirinya sendiri dan juga keyakinan akan kemampuan dirinya sendiri.

Harga diri dan efikasi diri yang berada di dalam diri seseorang akan menciptakan suatu motivasi yang baik sehingga dapat meningkatkan pencapaian prestasi seseorang. Motivasi bukan merupakan suatu kondisi namun motivasi timbul dari dalam diri manusia sendiri yaitu dengan adanya keinginan untuk dapat mengerjakannya dan menyelesaikan sesuatu dengan baik dan benar. Motivasi dirumuskan sebagai dorongan, baik diakibatkan faktor dari dalam maupun luar, untuk mencapai tujuan tertentu guna memenuhi atau memuaskan suatu kebutuhan. Peran motivasi dalam proses belajar dapat dianalogikan sebagai bahan bakar untuk menggerakkan mesin, motivasi belajar yang memadai akan mendorong siswa berperilaku aktif untuk berprestasi, tetapi motivasi yang terlalu kuat justru dapat berpengaruh negatif terhadap keefektifan usaha belajar dan yang nantinya akan mempengaruhi pencapaian prestasi yang akan didapatkan oleh anak. Berdasarkan pemikiran yang dipaparkan, penelitian ini bertujuan untuk menganalisis harga diri, efikasi diri, motivasi belajar, dan prestasi akademik siswa SMA pada berbagai model pembelajaran.

\section{METODE}

Penelitian ini menggunakan disain cross sectional. Kota Bogor dipilih secara purposive sebagai lokasi penelitian dengan pertimbangan 
bahwa lokasi tersebut memiliki perbedaan model pembelajaran. Pengambilan data dilakukan pada bulan April sampai dengan bulan Mei 2011.

Siswa yang dilibatkan dalam penelitian ini (contoh) adalah siswa kelas XI program akselerasi, RSBI, dan regular yang berjumlah 86 siswa. Jumlah siswa ini terdiri atas 26 siswa kelas akselerasi, 30 siswa kelas RSBI, dan 30 siswa kelas regular pada kelas XI IPA. Keseluruhan contoh yang dilibatkan dalam penelitian ini berjumlah 86 orang.

Ada dua jenis data yang dikumpulkan dalam penelitian ini, meliputi data primer dan data sekunder. Data primer terdiri atas karakteristik siswa, karakteristik keluarga siswa, harga diri, efikasi diri, dan motivasi belajar. Sementara itu, data sekunder yang digunakan adalah prestasi akademik. Pengumpulan data dilakukan dengan menggunakan teknik pelaporan diri (self report) dengan bantuan kuesioner penelitian.

Karakteristik siswa terdiri atas jenis kelamin, usia, dan urutan kelahiran. Umur anak dihitung berdasarkan tahun. Jenis kelamin anak dikategorikan menjadi laki-laki dan perempuan. Sementara itu, urutan kelahiran terdiri atas anak sulung, anak tengah, dan anak bungsu.

Karakteristik keluarga meliputi usia orang tua, pendidikan orang tua, pekerjaan orang tua, pendapatan keluarga, dan besar keluarga. Berdasarkan Papalia, Olds, \& Feldman (2001), umur orang tua dikategorikan menjadi dewasa muda (18-40 tahun), dewasa madya (41-60 tahun), dan dewasa akhir (> 60 tahun). Berdasarkan tingkat pendidikannya, pendidikan orang tua dikategorikan menjadi tidak tamat $\mathrm{SD}, \quad \mathrm{SD} /$ sederajat, $\quad \mathrm{SMP} /$ sederajat, SMA/sederajat, diploma, dan sarjana. Jenis pekerjaan orang tua terdiri atas tidak bekerja, wiraswasta, PNS, swasta, TNI/ABRI, buruh, pensiunan, dokter, dan supir. Pendapatan keluarga dikategorikan menjadi kurang dari atau sama dengan Rp1.000.000,00, antara $\mathrm{Rp} 1.000 .001,00$ dan $\mathrm{Rp} 2.000 .000,00$, antara 2.000.001,00 dan Rp3.000.000,00, antara Rp3.000.001,00 dan Rp4.000.000,00, serta lebih dari atau sama dengan Rp5.000.000,00. Sementara itu, besar keluarga dikategorikan menjadi keluarga kecil, keluarga sedang, dan keluarga besar.

Harga diri diukur dengan menggunakan 15 pernyataan dengan pilihan jawaban menggunakan skala Likert, yaitu sangat tidak sesuai (STS), tidak sesuai (TS), sesuai (S), dan sangat sesuai (SS). Instrumen yang digunakan ini merupakan modifikasi dari instrumen Texas Social Behavior Inventory Form yang disusun oleh Rosenberg (1967). Instrumen yang digunakan memiliki nilai Cronbach's alpha sebesar 0,646.

Efikasi diri diukur dengan menggunakan 30 pernyataan dengan pilihan jawaban menggunakan skala Likert, yaitu sangat tidak sesuai (STS), tidak sesuai (TS), sesuai (S), dan sangat sesuai (SS). Instrumen yang digunakan ini merupakan modifikasi dari instrumen Hambawany (2007). Instrumen yang digunakan memiliki nilai Cronbach's alpha sebesar 0,867.

Motivasi belajar siswa diukur dengan menggunakan 30 pertanyaan dengan pilihan jawaban menggunakan skala Likert, yaitu sangat tidak sesuai (STS), tidak sesuai (TS), sesuai (S), dan sangat sesuai (SS). Instrumen yang digunakan ini mengacu kepada Pelletier, et al. (1995). Instrumen yang digunakan memiliki nilai Cronbach's alpha sebesar 0,805.

Prestasi akademik siswa diukur menggunakan nilai rapor. Ada tiga aspek yang diperhatikan dalam menilai prestasi akademik siswa, yaitu aspek kognitif, psikomotor, dan afektif. Selanjutnya, persentase skor yang diperoleh pada variable harga diri, efikasi diri, motivasi belajar, dan prestasi akademik dikategorikan dalam tiga kategori yaitu tinggi $(>80 \%)$, sedang $(60 \%-80 \%)$, dan rendah $(<60 \%)$.

Data yang diperoleh dianalisis secara deskriptif dan statistik inferensia (korelasi Spearman, korelasi Pearson, dan uji beda OneWay ANOVA). Analisis deskriptif digunakan untuk menghitung nilai minimum, maksimum, rata-rata, dan standar deviasi. Uji korelasi Spearman dan Pearson digunakan untuk menganalisis hubungan antarvariabel penelitian. Sementara itu, uji beda One-Way ANOVA digunakan untuk menganalisis perbedaan antarvariabel penelitian berdasarkan kelas (akselerasi, SBI, dan regular).

HASIL

\section{Karakteristik Siswa}

Hasil penelitian menunjukkan bahwa tiga dari lima siswa berjenis kelamin perempuan. Rata-rata usia siswa kelas akselerasi adalah 15 tahun, sedangkan rata-rata usia kelas SBI dan regular adalah 16 tahun. Berdasarkan urutan kelahiran, separuh siswa (52,3\%) termasuk dalam kategori anak sulung. 


\section{Karakteristik Keluarga}

Hasil penelitian menunjukkan bahwa sebagian besar orang tua siswa dari ketiga kelas termasuk dalam usia dewasa madya (4160 tahun). Tiga dari lima ayah dan dua dari lima ibu siswa berpendidikan hingga S1/S2/S3. Hasil penelitian juga menunjukkan bahwa empat dari sepuluh ayah bekerja di sektor swasta, sedangkan ibu $(60,5 \%)$ bekerja sebagai ibu rumah tangga. Keluarga siswa memiliki pendapatan pada rentang $\geq R p 5.000 .001,00$. Pendapatan keluarga yang dimiliki siswa kelas akselerasi dan SBI lebih besar dibandingkan dengan pendapatan keluarga siswa kelas regular. Hasil uji beda juga menunjukkan bahwa terdapat perbedaan yang signifikan antara pendapatan keluarga siswa berdasarkan kelas. Berdasarkan besar keluarga, tiga dari lima keluarga siswa tergolong keluarga sedang.

\section{Harga Diri}

Setiap anak pasti memiliki penilaian terhadap dirinya sendiri secara umum yang dikenal dengan istilah harga diri (self-esteem). Harga diri seseorang dipengaruhi oleh reaksi orang lain dan perbandingan dengan orang lain (Mcilveen \& Gross, 1997). Hasil penelitian menunjukan bahwa lebih dari dua per tiga siswa pada kelas akselarasi $(76,9 \%)$, SBI $(66,7 \%)$, dan reguler $(83,3 \%)$ memiliki harga diri pada kategori sedang (Tabel 1). Siswa yang memiliki harga diri pada kategori tinggi merasa dirinya berharga, merasa mempunyai sifat-sifat yang baik pada dirinya, selalu bersikap positif terhadap dirinya sendiri, merasa sering ditiru oleh orang lain, dan merasa mempunyai sesuatu yang dapat dibanggakan pada dirinya. Siswa yang memiliki harga diri pada kategori rendah merasa tidak berguna, tidak diperhatikan oleh orang lain, tidak memiliki sesuatu yang dapat dibanggakan, dan merasa tidak diberi tanggung jawab. Hasil uji beda menunjukan bahwa harga diri siswa berdasarkan model pembelajaran tidak berbeda signifikan $(p>0,05)$.

Tabel 1 Sebaran siswa berdasarkan kategori harga diri pada berbagai model pembelajaran dan koefisien uji beda

\begin{tabular}{lrrr}
\hline \multirow{2}{*}{ Kategori } & \multicolumn{3}{c}{ Model pembelajaran } \\
\cline { 2 - 4 } & Akselerasi & \multicolumn{1}{c}{ SBI } & Reguler \\
\hline Tinggi & 7,7 & 26,7 & 16,7 \\
Sedang & 76,9 & 66,7 & 83,3 \\
Rendah & 15,4 & 6,7 & 0,0 \\
\hline Total & 100,0 & 100,0 & 100,0 \\
Min-maks & $26-55$ & $34-54$ & $36-59$ \\
Rata-rata \pm & $41,9 \pm 6,3$ & $45,2 \pm 5,3$ & $43,5 \pm 4,9$ \\
std (skor) & & 0,089 & \\
p-value & & & \\
\hline
\end{tabular}

Tabel 2 Sebaran siswa berdasarkan kategori self-efficacy pada berbagai model pembelajaran dan koefisien uji beda

\begin{tabular}{lrrr}
\hline \multirow{2}{*}{ Kategori } & \multicolumn{3}{c}{ Model pembelajaran } \\
\cline { 2 - 4 } & Akselerasi & \multicolumn{1}{c}{ SBI } & Reguler \\
\hline Tinggi & 15,4 & 6,7 & 13,3 \\
Sedang & 80,8 & 93,3 & 86,7 \\
Rendah & 3,8 & 0,0 & 0,0 \\
\hline Total & 100,0 & 100,0 & 100,0 \\
Min-maks & $70-107$ & $74-110$ & $72-108$ \\
Rata-rata \pm std & $85,5 \pm 10,2$ & $85,7 \pm 7,9$ & $84,7 \pm$ \\
(skor) & \multicolumn{3}{c}{0,916} \\
p-value & \multicolumn{3}{c}{9,1} \\
\hline
\end{tabular}

\section{Efikasi Diri}

Setiap orang memiliki kayakinan untuk pencapaian prestasi agar prestasinya tinggi dan dapat menguasai situasi yang dihadapinya (Bandura, 1986). Keyakinan seperti ini disebut dengan efikasi diri. Hasil penelitian menunjukan bahwa sebagian besar siswa kelas akselerasi $(80,3 \%)$, SBI $(93,3 \%)$, dan regular $(86,7 \%)$ memiliki efikasi diri pada kategori sedang (Tabel 2). Siswa yang memiliki efikasi diri tinggi merasa yakin untuk meng-hadapi tantangan masa depan, merasa mampu menyelesaikan tugas-tugas yang diberikan kepadanya, semakin semangat mengerjakan tugas yang dianggapnya sulit, dan mengetahui kiat yang pas untuk menyelesaikan berbagai macam tugas dengan baik. Siswa yang memiliki efikasi diri yang rendah merasa tidak yakin dapat menyelesaikan tugas yang diberikan kepadanya, tidak dapat menyelesai-kan tugas dengan baik apabila tidak dibantu oleh orang lain, mudah menyerah apabila menghadapi kesulitan, dan sering kali rendah diri melihat temannya yang dapat menyelesai-kan tugas dengan baik. Hasil uji beda menunjukkan bahwa tidak ada perbedaan yang signifikan antara efikasi diri pada siswa kelas akselerasi, $\mathrm{SBI}$, dan reguler $(p>0,05)$.

\section{Motivasi Belajar}

Motivasi yang dimiliki oleh seseorang sangat berpengaruh dengan tindakan yang akan dilakukannya dan apa yang akan menjadi tujuannya serta menjaga seseorang untuk tetap bekerja pada aktivitas tertentu. Motivasi yang diukur dalam penelitian ini adalah motivasi intrinsik dan motivasi ekstrinsik. Motivasi intrinsik adalah dorongan yang berasal dari dalam dirinya sendiri untuk menyelesaikan dan mengerjakan sesuatu. Hasil penelitian menunjukan bahwa persentase terbesar siswa kelas akselerasi $(88,5 \%)$, SBI $(73,3 \%)$, dan reguler $(63,3 \%)$ memiliki motivasi intrinsik dalam kategori sedang (Tabel 3 ). 
Tabel 3 Sebaran siswa berdasarkan motivasi belajar pada berbagai model pembelajaran

\begin{tabular}{|c|c|c|c|}
\hline \multirow{2}{*}{ Kategori } & \multicolumn{3}{|c|}{ Model pembelajaran } \\
\hline & Akselerasi & SBI & Reguler \\
\hline \multicolumn{4}{|c|}{ Motivasi Intrinsik } \\
\hline Tinggi & 7,7 & 26,7 & 33,3 \\
\hline Sedang & 88,5 & 73,3 & 63,3 \\
\hline Rendah & 3,8 & 0,0 & 3,3 \\
\hline Total & 100,0 & 100,0 & 100,0 \\
\hline $\begin{array}{l}\text { Rata-rata } \pm \\
\text { standar } \\
\text { deviasi (skor) }\end{array}$ & $\begin{array}{r}43,4 \pm \\
4,0\end{array}$ & $\begin{array}{r}47,6 \pm \\
4,6\end{array}$ & $\begin{array}{r}47,9 \pm \\
7,8\end{array}$ \\
\hline$p$-value & \multicolumn{3}{|c|}{0,000} \\
\hline \multicolumn{4}{|c|}{ Motivasi Ekstrinsik } \\
\hline Tinggi & 23,1 & 20,0 & 20,0 \\
\hline Sedang & 76,9 & 80,0 & 80,0 \\
\hline Total & 100,0 & 100,0 & 100,0 \\
\hline $\begin{array}{l}\text { Rata-rata } \pm \\
\text { standar } \\
\text { deviasi (skor) }\end{array}$ & $\begin{array}{r}46,1 \pm \\
4,5\end{array}$ & $\begin{array}{r}45,4 \pm \\
4,1\end{array}$ & $\begin{array}{r}45,3 \pm \\
5,7\end{array}$ \\
\hline$p$-value & \multicolumn{3}{|c|}{0,724} \\
\hline \multicolumn{4}{|l|}{ Motivasi } \\
\hline Tinggi & 15,4 & 33,3 & 33,3 \\
\hline Sedang & 84,6 & 66,7 & 66,7 \\
\hline Total & 100,0 & 100,0 & 100,0 \\
\hline $\begin{array}{l}\text { Rata-rata } \pm \\
\text { standar } \\
\text { deviasi (skor) }\end{array}$ & $\begin{array}{r}85,5 \pm \\
7,6\end{array}$ & $\begin{array}{r}93,0 \pm \\
7,5\end{array}$ & $\begin{array}{r}93,2 \pm \\
7,1\end{array}$ \\
\hline$p$-value & & 0,120 & \\
\hline
\end{tabular}

Hasil uji beda menunjukan terdapat perbedaan yang signifikan antara motivasi intrinsik yang dimiliki siswa kelas akelerasi, SBI, dan reguler $(p<0,05)$. Siswa kelas reguler mempunyai skor rata-rata motivasi instrinsik tertinggi dan siswa kelas akselerasi mempunyai skor rata-rata motivasi instrinsik terendah.

Jenis motivasi belajar yang kedua yang diukur dalam penelitian ini adalah motivasi ekstrinsik. Motivasi ekstrinsik merupakan motivasi yang didapatkan dari dorongan luar seperti orang tua, teman, guru dan lainnya. Hasil penelitian menunjukan bahwa persentase terbesar motivasi ekstrinsik siswa kelas akselerasi $(76,9 \%)$, kelas SBI $(76,7 \%)$, dan kelas reguler $(80,0 \%)$ adalah kategori sedang. Hasil uji beda menunjukan bahwa tidak terdapat perbedaan yang signifikan antara motivasi ekstrinsik yang dimiliki siswa kelas akelerasi, SBI, dan reguler $(p>0,05)$. Secara keseluruhan, motivasi belajar siswa kelas akselerasi $(84,6 \%)$, SBI $(66,7 \%)$, dan regular $(66,7 \%)$ berada pada kategori sedang (Tabel 3). Hasil uji beda menunjukan bahwa tidak terdapat perbedaan motivasi belajar yang dimiliki siswa pada kelas akelerasi, SBI, dan reguler $(p>0,05)$. Sejalan dengan temuan tentang motivasi instrinsik, meskipun tidak ada perbedaan yang nyata namun penelitian ini menemukan bahwa siswa kelas reguler mempunyai motivasi ekstrinsik dengan rata-rata skor terendah pada siswa kelas akselerasi mempunyai skor rata-rata motivasi ekstrinsik tertinggi.

\section{Prestasi Akademik}

Prestasi akademik siswa di sekolah dinilai dari nilai rapor, mencakup nilai kognitif, nilai psikomotorik, dan nilai afektif. Nilai kognitif adalah nilai yang bersifat akademis didapatkan dari hasil ujian dan nilai tugas harian. Nilai psikomotorik berasal dari nilai praktikum. Sementara itu, nilai afektif didapat dari sikap dan minat siswa. Hasil penelitian menunjukan bahwa seluruh siswa kelas akselerasi (100\%) memiliki nilai kognitif, nilai psikomotorik, dan nilai afektif yang tergolong kategori tinggi. Siswa pada kelas SBI memiliki nilai kognitif kategori sedang $(56,7 \%)$, nilai psikomotorik kategori tinggi $(96,7 \%)$, dan nilai afektif kategori tinggi $(100 \%)$. Seluruh siswa kelas reguler memiliki nilai kognitif kategori sedang, nilai psikomotorik kategori sedang, dan nilai afektif kategori tinggi (Tabel 4).

Tabel 4 Sebaran siswa berdasarkan aspek prestasi akademik

\begin{tabular}{|c|c|c|c|}
\hline \multirow{2}{*}{ Kategori } & \multicolumn{3}{|c|}{ Model pembelajaran } \\
\hline & Akselerasi & SBI & Reguler \\
\hline \multicolumn{4}{|l|}{ Kognitif } \\
\hline Sedang & 0,0 & 56,7 & 100,0 \\
\hline Tinggi & 100,0 & 43,3 & 0,0 \\
\hline Total & 100,0 & 100,0 & 100,0 \\
\hline Min-maks & $81-88$ & $77-86$ & $75-79$ \\
\hline $\begin{array}{l}\text { Rata-rata } \pm \\
\text { standar } \\
\text { deviasi (skor) }\end{array}$ & $83,1 \pm 1,8$ & $\begin{array}{r}80,3 \pm \\
2,1\end{array}$ & $\begin{array}{r}76,9 \pm \\
0,9\end{array}$ \\
\hline$p$-value & \multicolumn{3}{|c|}{0,000} \\
\hline \multicolumn{4}{|l|}{ Psikomotor } \\
\hline Sedang & 0,0 & 3,3 & 100,0 \\
\hline Tinggi & 100,0 & 96,7 & 0,0 \\
\hline Total & 100,0 & 100,0 & 100,0 \\
\hline Min-maks & $83-86$ & $80-84$ & $76-79$ \\
\hline $\begin{array}{l}\text { Rata-rata } \pm \\
\text { standar } \\
\text { deviasi (skor) }\end{array}$ & $84,0 \pm 0,9$ & $\begin{array}{r}81,2 \pm \\
0,9\end{array}$ & $\begin{array}{r}77,8 \pm \\
0,8\end{array}$ \\
\hline$p$-value & \multicolumn{3}{|c|}{0,000} \\
\hline \multicolumn{4}{|l|}{ Afektif } \\
\hline Tinggi & 100,0 & 100,0 & 100,0 \\
\hline Total & 100,0 & 100,0 & 100,0 \\
\hline Min-maks & $3,3-3,8$ & $3,1-3,8$ & $3,5-3,9$ \\
\hline $\begin{array}{l}\text { Rata-rata } \pm \\
\text { standar } \\
\text { deviasi (skor) }\end{array}$ & $3,6 \pm 0,2$ & $\begin{array}{r}3,4 \pm \\
0,2\end{array}$ & $\begin{array}{r}3,3 \pm \\
0,1\end{array}$ \\
\hline$p$-value & & 0,000 & \\
\hline
\end{tabular}


Hasil uji beda menunjukkan bahwa terdapat perbedaan yang signifikan antara nilai kognitif, nilai psikomotorik, dan nilai afektif dikelas akselerasi, kelas SBI dan kelas reguler $(p<0,05)$. Siswa kelas akselerasi mempunyai skor rata-rata tertinggi untuk ketiga aspek prestasi akademik dibandingkan kelas SBI dan reguler. Sementara siswa kelas reguler mempunyai rata-rata skor untuk ketiga aspek prestasi akademik dengan nilai terendah.

\section{Hubungan Antarvariabel Penelitian}

Analisis korelasi menunjukkan bahwa usia anak berhubungan signifikan dengan harga diri $(r=0,258, p<0,05)$. Semakin tinggi usia anak maka semakin besar harga diri yang dimiliki oleh anak. Analisis korelasi juga menunjukkan bahwa harga diri berhubungan signifikan dengan efikasi diri $(r=0,567, p<0,01)$, motivasi intrinsik $(r=0,520, \quad p<0,01)$, dan motivasi ekstrinsik $(r=0,289, p<0,01)$. Motivasi intrinsik berhubungan signifikan dengan motivasi ekstrinsik $(r=0,437, p<0,01)$. Efikasi diri juga berhubungan signifikan dengan motivasi intrinsik $(r=0,451, \quad p<0,05) \quad$ dan motivasi ekstrinsik $(r=0,420, p<0,01)$. Motivasi intrinsik berhubungan signifikan negatif dengan prestasi akademik pada aspek kognitif $(r=-0,217$, $\mathrm{p}<0,05)$ dan aspek psikomotor $(r=-0,256$, $p<0,05)$. Prestasi akademik aspek kognitif berhubungan signifikan dengan prestasi akademik pada aspek psikomotor $(r=0,929$, $p<0,01)$.

\section{PEMBAHASAN}

Salah satu faktor yang penting dalam perkembangan kepribadian remaja adalah harga diri (self-esteem). Harga diri merupakan penilaian seseorang terhadap dirinya sendiri, baik berupa penilaian negatif maupun penilaian positif yang akhirnya menghasilkan perasaan keberhargaan atau kebergunaan diri dalam menjalani kehidupan (Coopersmith, 1967). Analisis korelasi menunjukkan bahwa harga diri berhubungan signifikan dengan usia anak. Semakin tinggi usia anak maka semakin baik pula harga diri yang dimiliki oleh anak. Menurut Frey (1983), ketika lahir bayi tidak dilengkapi dengan konsep harga diri dan tidak dapat membedakan dirinya dengan lingkungannya. Harga diri diperoleh melalui interaksi sosial dengan keluarga dan orang lain yang dijumpainya selama hidup. Oleh sebab itu, semakin tinggi usia maka semakin banyak orang yang dijumpai dan penilaian mereka terhadap dirinya sendiri akan semakin terlihat dan semakin baik. Pertambahan usia individu dapat meningkatkan kemampuan individu dalam mengevaluasi perilaku dan penampilannya sehingga membentuk penilaian mengenai diri sendiri. Pada usia lebih dewasa, seorang individu cenderung memiliki harga diri yang tinggi untuk menggapai cita-citanya.

Selain harga diri, salah satu yang menjadi faktor penting dalam kepribadian remaja adalah efikasi diri (self-efficacy). Menurut Bandura, diacu dalam Santrock (2002), efikasi diri adalah keyakinan seseorang akan kemampuan dirinya untuk menguasai situasi dan menghasilkan hasil yang positif. Menurut Pajares (2006), efikasi diri adalah suatu keadaan dimana seseorang yakin dan percaya bahwa mereka dapat mengontrol hasil dari usaha yang telah dilakukan. Hasil penelitian menunjukkan bahwa sebagian besar siswa memiliki tingkat efikasi diri pada kategori sedang.

Harga diri dan efikasi diri merupakan faktor penting dalam perkembangan remaja, namun ada lagi yang tidak kalah penting yaitu motivasi belajar. Motivasi adalah keadaan internal yang menyebabkan seseorang bertindak, mendorong pada arah tertentu, dan menjaga individu tetap bekerja pada aktivitas tertentu (Santrock, 2008). Pentingnya peranan motivasi dalam proses belajar perlu dipahami oleh pendidik agar dapat melakukan berbagai bentuk tindakan atau bantuan kepada siswa. Motivasi dirumuskan sebagai dorongan, baik dari dalam maupun luar untuk mencapai tujuan tertentu. Menurut Santrock (2008) motivasi terdapat dua macam motivasi, yaitu motivasi ekstrinsik dan intrinsik. Motivasi ekstrinsik adalah melakukan sesuatu untuk mendapatkan sesuatu yang lain (cara untuk mencapai tujuan) dan dipengaruhi oleh dorongan dari luar. Motivasi intrinsik merupakan motivasi internal untuk melakukan sesuatu demi sesuatu itu sendiri (tujuan itu sendiri).

Harga diri memiliki hubungan yang nyata dan positif dengan motivasi intrinsik dan motivasi ekstrinsik, yang menunjukkan bahwa semakin baik harga diri yang dimiliki oleh seseorang, maka semakin tinggi motivasi intrinsik dan motivasi ekstrinsik yang dimilikinya. Hasil ini sejalan dengan pendapat dari Harter (1983) yang menyebutkan bahwa ada dua sumber yang digunakan oleh anak untuk membangun harga diri yaitu sumber dari dalam dan dari luar individu itu sendiri. Sumbersumber tersebut merupakan motivasi seseorang untuk membangun harga diri yang dimilikinya sehingga harga diri berhubungan dengan motivasi intrinsik dan motivasi ekstrinsik. 
Hasil penelitian juga menunjukan bahwa efikasi diri berhubungan nyata dan positif dengan motivasi intrinsik dan motivasi ekstrinsik. Artinya semakin baik efikasi diri yang dimiliki seseorang maka semakin tinggi motivasi intrinsik dan ekstrinsik yang dimilikinya. Keyakinan terhadap kemampuan diri sendiri akan membuat seseorang memiliki motivasi untuk mengerjakan segala sesuatunya dan menyelesaikan pekerjaannya dengan baik karena ia yakin bahwa dirinya mampu untuk menyelessaikan tugas tersebut (Bandura, 1982). Menurut Morris dan Summers (1995), karena efikasi diri mempunyai hubungan yang erat dengan motivasi maka selain berpengaruh terhadap performa, efikasi diri juga berpengaruh terhadap motivasi individu.

Rata-rata skor motivasi ekstrinsik yang tertinggi terdapat pada kelas akselerasi. Hal ini membuktikan bahwa siswa dan siswi kelas akselerasi motivasi terbesarnya adalah motivasi ekstrinsik yaitu dorongan dari luar seperti guru, lingkungan, dan teman sebayanya. Hal ini sejalan dengan penelitian dari Kurniawan (2010) yang menyatakan bahwa anak-anak yang masuk ke dalam kelas akselerasi lebih banyak karena kehendak orang tua sehingga motivasi belajar yang dimilikinya pun lebih banyak merupakan dorongan dari luar tidak dari dalam dirinya sendiri. Selain itu persaingan pada kelas akselerasi pun sangat tinggi karena anak-anak di kelas tersebut merupakan anakanak yang memiliki IQ tinggi sehingga mereka berlomba-lomba untuk mendapatkan hasil yang lebih baik dan hal tersebut menyebabkan persaingan pun semakin tinggi. Standar yang ditetapkan oleh sekolah di kelas akselerasi pun lebih tinggi dibandingkan kelas lain, hal ini menyebabkan dorongan dari luar yaitu sekolah mereka pun semakin tinggi.

Sementara itu, rata-rata skor motivasi ekstrinsik tertinggi didapatkan oleh siswa-siswi dari kelas reguler. Hal ini terjadi karena lingkungan kelas reguler seperti fasilitas belajar mengajarnya pun tidak sebaik kelas akselerasi dan kelas SBI, sehingga dorongan belajar terkuat didapatkannya dari dalam dirinya sendiri. Menurut Suryabrata (1995) motivasi seseorang didorong oleh keinginan dirinya sendiri dan juga oleh dorongan dari luar. Salah satu yang berhubungan dengan motivasi dalam penelitian ini adalah harga diri (penilaian terhadap dirinya) dan efikasi diri (keyakinan diri seseorang). Seseorang yang memiliki harga diri dan efikasi diri yang tinggi maka akan memiliki motivasi yang tinggi pula. Penelitian ini menunjukan bahwa harga diri dan efikasi diri siswa dalam penelitian ini berada dalam kategori sedang, begitu juga dengan motivasinya yang berada dalam keadaan sedang pula.

Selain itu, penelitian ini juga mengukur prestasi akademik siswa-siswi yang menjadi siswa penelitian dengan melihat hasilnya dari nilai rapor mereka. Di dalam nilai rapor prestasi akademik terdiri dari tiga aspek penilaian yaitu aspek kognitif, aspek psikomotorik, dan aspek afektif. Penelitian menunjukan bahwa seluruh siswa kelas akselerasi memiliki nilai kognitif yang berada dalam kategori tinggi. Separuh siswa kelas SBI memiliki persentase yang tinggi pada kategori sedang dan seluruh siswa pada kelas reguler berada dalam kategori sedang. Menurut Depdikbud (2006) siswa-siswi yang masuk ke dalam kelas akselerasi adalah siswasiswi yang memiliki kemampuan di atas ratarata sehingga sesuai dengan hasil penelitian yang diperoleh bahwa seluruh siswa kelas akselerasi memiliki nilai kognitif yang tinggi.

Selain aspek kognitif ada pula yang disebut dengan aspek psikomotorik. Dari hasil penelitian didapatkan bahwa seluruh siswa kelas akselerasi dan sebagian siswa kelas SBI memiliki nilai psikomotorik yang berada dalam kategori sedang sedangkan seluruh siswa pada kelas reguler memiliki nilai psikomotorik dalam kategori sedang. Suryabrata (1995) menyebutkan bahwa nilai psikomotorik adalah nilai yang didapatkan oleh anak dengan penilaian kemampuan keterampilan fisik mereka dalam mengerjakan atau menyelesaikan sesuatu. Temuan ini menunjukkan bahwa keterampilan anak-anak kelas akselerasi dan SBI lebih tinggi capaiannya daripada kelas reguler.

Aspek penilaian prestasi lain yang diukur dalam penelitian ini adalah nilai afektif. Menurut Suryabrata (1995) nilai afektif mencakup kemampuan menyangkut aspek perasaan dan emosi yang terbagi dalam beberapa bagian yaitu penerimaan terhadap lingkungannya, tanggapan dan respon terhadap lingkungan serta penghargaan dalam bentuk ekspresi terhadap sesuatu. Berdasarkan penelitian seluruh siswa baik dalam kelas akselerasi, kelas SBI, dan kelas reguler memiliki nilai afektif yang masuk dalam kategori tinggi. Hal ini menunjukan bahwa seluruh siswa-siswi apapun model pembelajarannya, memiliki kemampuan terhadap perasaan dan emosi yang baik dan juga penerimaan terhadap lingkungan yang baik. Perbedaan perolehan prestasi yang didapatkan pada kelas akselerasi, kelas SBI, dan kelas reguler ini dapat terjadi karena adanya perbedaan lingkungan atau metode 
pembelajaran serta kemampuan terhadap penguasaan materi antara kelas akselerasi dengan kelas RSBI dan reguler.

Menurut Mc.Clelland (1995), motivasi belajar berhubungan dengan kebutuhan untuk berprestasi yang mengarahkan seseorang dalam bertindak untuk mencapai prestasi. Selain itu motivasi belajar juga menjadi dorongan seseorang untuk mencapai hasil yang sebaik-baiknya. Dalam penelitian ini didapatkan hubungan antara motivasi belajar intrinsik dengan prestasi belajar yaitu nilai kognitif dan nilai psikomotorik, namun hubungan dalam penelitian ini bersifat negatif. Artinya semakin tinggi motivasi intrinsik yang dimiliki oleh anak, maka semakin rendah nilai kognitif dan psikomotorik mereka. Hal ini diduga terjadi karena rata-rata terbesar motivasi intrinsik yang dimiliki oleh siswa kelas reguler, sedangkan rata-rata prestasi mereka yaitu nilai kognitif dan nilai psikomotoriknya berada dalam rata-rata yang paling rendah dari ketiga kelas tersebut. Selain itu menurut Adi, diacu dalam Gunarsa dan Gunarsa (2006), motivasi memang merupakan salah satu faktor yang menentukan prestasi tetapi diantara itu jangan pula dilupakan terdapat kemampuan anak untuk menyerap pelajaran sehingga walaupun merepa memiliki motivasi yang tinggi di dalam dirinya, belum tentu memiliki kemampuan menyerap pelajaran yang baik pula untuk mendapatkan prestasi yang tinggi.

\section{SIMPULAN DAN SARAN}

Hasil penelitian menunjukkan bahwa sebagian besar siswa kelas akselerasi, SBI, dan regular memiliki harga diri, efikasi diri, dan motivasi belajar (intrinsik dan ekstrinsik) pada kategori sedang. Hasil penelitian juga menunjukkan bahwa seluruh siswa kelas akselerasi memiliki nilai kognitif, nilai psikomotorik, dan nilai afektif yang tergolong kategori tinggi. Siswa pada kelas SBI memiliki nilai kognitif kategori sedang, nilai psikomotorik dan afektif kategori tinggi. Seluruh siswa kelas reguler memiliki nilai kognitif dan psikomotorik kategori sedang, serta nilai afektif kategori tinggi.

Analisis korelasi memperlihatkan bahwa usia anak berhubungan signifikan dengan harga diri. Harga diri berhubungan signifikan dengan efikasi diri, motivasi intrinsik, dan motivasi ekstrinsik. Motivasi intrinsik berhubungan signifikan dengan motivasi ekstrinsik. Selain itu, efikasi diri juga berhubungan signifikan dengan motivasi intrinsik dan motivasi ekstrinsik. Motivasi intrinsik berhubungan signifikan negatif dengan prestasi akademik pada aspek kognitif dan aspek psikomotor. Prestasi akademik aspek kognitif berhubungan signifikan dengan prestasi akademik pada aspek psikomotor. Sementara itu, analisis uji beda menunjukan terdapat perbedaan yang signifikan antara motivasi intrinsik, nilai kognitif, nilai psikomotorik, dan nilai afektif yang dimiliki siswa kelas akelerasi, $\mathrm{SBI}$, dan reguler.

Berdasarkan hasil, penelitian ini menyarankan sekolah untuk memfasilitasi dan memberikan program-program yang dapat meningkatkan harga diri siswa yaitu dengan adanya pembinaan yang berkesinambungan mengenai pengenalan dan penilaian terhadap kemampuan diri sendiri sehingga siswa memiliki penilaian yang positif terhadap dirinya sendiri. Penilaian yang positif akan menghasilkan seseorang anak memiliki keyakinan yang positif pula terhadap kemampuannya sehingga seorang anak akan mendapatkan nilai yang baik dan mengerjakan tugasnya dengan baik.

\section{DAFTAR PUSTAKA}

Alisjahbana, S. T. (2000). Antropologi Baru, Jakarta: Dian Rakyat.

Bandura, A. (1982). Self-efficacy Mecahanism on Human Agency. American Psychologist. New Jersey: Prentice Hall.

(1986). Social Foundation of Tought and Action: A social Cognitive Theory. New Jersey: Prentice-Hall.

Coopersmith, S. (1967). The Antecendent Of Self Esteem. San Fransisco: C. H. Freeman and Compeny.

[Depdikbud] Dinas Pendidikan dan Kebudayaan. 2006. Undang-undang RI Nomor 20 tahun 2003 tentang Sistem Pendidikan Nasional. Jakarta: WIPRESS.

Frey, D. (1983). Enchancing Self Esteem. Indiana: Accelerated Development Inc.

Gunarsa, S. D., \& Gunarsa, Y. S. D. (2006). Psikologi Perkembangan Anak dan Remaja. Jakarta: Gunung Mulia.

Hambawany, E. (2007). Hubungan Antara Self Efficacy dan Persepsi Anak Terhadap Perhatian Orang Tua dengan Prestasi Belajar pada Penyandang Tuna Daksa [Skripsi]. Surakarta: Universitas Muhammdiyah Surakarta. 
Harter, S. (1983). Development Perspective on The Self System. Museen, P. H., editor. Handbook of Child Psychology $\left(4^{\text {th }}\right)$. New York: John.

[HDR] Human Development Report. (2008). Human Development Index.

Kurniawan. (2010). Evaluasi Program Akselerasi: Kelas Siswa Cerdas Istimewa Berbakat Istimewa [Tesis]. Bogor: Sekolah Pascasarjana, Institut Pertanian Bogor.

McClelland, D. C. (1995). Memacu masyarakat Berprestasi: Mempercepat Laju Pertumbuhan Ekonomi Melalui Peningkatan Motif Berprestasi. Jakarta: Intermedia.

Mcilveen, R., \& Gross, R. (1997). Development Psychology. London: Hodder \& Stoughton.

Morris, T., \& Summer, J. (1995). Sport Psychology: Theory, Applications and Issues. Brisbane: John Wiley \& Sons.
Pajares, F. (2006). Self-efficacy Beliefs Of Adolescents. Greenwich Connecticut: Information Age Publishing, Inc.

Papalia, D. E., Old, S. W., \& Feldman, R. D. (2001). Human development (8th Ed.). Boston: McGraw Hill.

Pelletier, et al. (1995). Te Sport Motivation scale. Journal of Sport \& Exercise Psychology, 17, 35-53.

Rosenberg, M. (1967). Texas Social Behavior Inventory.

Santrock, J. W. (2002). Life Span Development: Perkembangan Masa Hidup. Damanik, J., Chusairi, A., penerjemah. Kristiaji, W. C., \& Sumiharti, Y., editor. Jakarta: Erlangga. Jakarta: Kencana.

Suryabrata, S. (1995). Psikologi Pendidikan. Jakarta: Raja Grafindo Persada. 